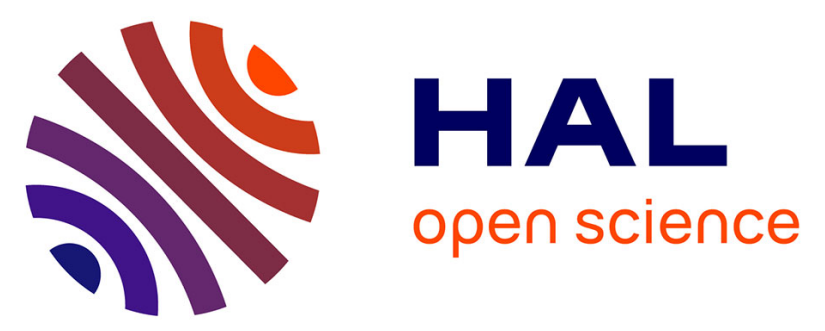

\title{
Further studies on the photoreactivities of ruthenium-nitrosyl complexes with terpyridyl ligands
}

Isabelle Sasaki, Silvia Amabilino, Sonia Mallet-Ladeira, Marine Tassé, Alix Sournia-Saquet, Pascal G. Lacroix, Isabelle Malfant

\section{- To cite this version:}

Isabelle Sasaki, Silvia Amabilino, Sonia Mallet-Ladeira, Marine Tassé, Alix Sournia-Saquet, et al.. Further studies on the photoreactivities of ruthenium-nitrosyl complexes with terpyridyl ligands. New Journal of Chemistry, 2019, 43 (28), pp.11241-11250. 10.1039/C9NJ02398D . hal-02321845

\section{HAL Id: hal-02321845 \\ https://hal.science/hal-02321845}

Submitted on 4 Nov 2020

HAL is a multi-disciplinary open access archive for the deposit and dissemination of scientific research documents, whether they are published or not. The documents may come from teaching and research institutions in France or abroad, or from public or private research centers.
L'archive ouverte pluridisciplinaire HAL, est destinée au dépôt et à la diffusion de documents scientifiques de niveau recherche, publiés ou non, émanant des établissements d'enseignement et de recherche français ou étrangers, des laboratoires publics ou privés. 


\title{
Journal Name
}

\section{Further studies on the photoreactivities of ruthenium-nitrosyl complexes with terpyridyl ligands.}

Received 00th January 20xx, Accepted 00th January 20xx

DOI: $10.1039 / \times 0 \times x 00000 x$

www.rsc.org/

\begin{abstract}
Isabelle Sasaki, ${ }^{\mathrm{a}, \mathrm{b}}$ Silvia Amabilino, ${ }^{\mathrm{a}}$ Sonia Mallet-Ladeira, ${ }^{\mathrm{a}}$ Marine Tassé, ${ }^{\mathrm{a}}$ Alix Sournia-Saquet, ${ }^{\mathrm{a}}$ Pascal G. Lacroix ${ }^{a}$ and Isabelle Malfant* ${ }^{a}$

This study focuses on the two cis/trans- $(\mathrm{Cl}, \mathrm{Cl})-\left[\mathrm{Ru}(\mathrm{R}-\mathrm{Phtpy}) \mathrm{Cl}_{2}(\mathrm{NO})\right]^{+}$isomers, where the $\mathrm{R}$ group is a $\mathrm{NEt}_{2}$ on the $4^{\prime}-$ position of the phenylterpyridine (Phtpy). The photophysical characteristics properties of the two isomers as well as those of one nitrosamine derivative are described. The NO release properties are evaluated and show that the cis isomer is the most efficient with a good quantum yield of NO release. X-ray structures of three ruthenium-nitrosyl complexes and one of a photoproduct are presented.
\end{abstract}

\section{Introduction}

Nitric oxide (NO), known as an atmospheric pollutant, has become the source of intensive and exciting research in animals, since its identification as an endothelium-derived relaxing factor (EDRF) in the 1980 s. $^{1}$ NO is a gaseous radical species with a half-life of a few seconds and is produced by a family of NO synthases (NOS) identified as: neuronal NOS (nNOS), inducible NOS (iNOS), and endothelial NOS (eNOS). NO is recognized as a broad-spectrum biological signalling molecule that operates at both systemic and specific cellular levels. ${ }^{1}$ The participation of NO in various physiological roles such as neurotransmission, ${ }^{2}$ immunology, ${ }^{3}$ local blood flow and platelet function ${ }^{4}$, vasodilatation, ${ }^{5}$ angiogenesis ${ }^{6}$ etc. is well established. NO balance and bioavailability are of primary importance in the regulation of these various physiological processes. In order to deliver NO in a controlled manner, during the past few decades, researches have aimed to develop NO-donors prodrugs as potential therapeutics that exploit NO's vast biological roles. Among them, metal nitrosyl compounds became extremely popular thanks to their ability to deliver NO after photoactivation. ${ }^{7}$ In particular, ruthenium-nitrosyl complexes, because they offered superior design flexibility and solution stability compared to oxygen-sensitive Fe and $\mathrm{Mn}$ congeners. ${ }^{8}$ Numerous recent reviews have reported their NO release under irradiation. ${ }^{9}$

For instance, our group studied ruthenium-nitrosyl complexes with

\footnotetext{
a. LCC, UPR 8241, 205 route de Narbonne, 31077 Toulouse Cedex, France.

b. Current address, ISM, 351, cours de la Libération, 33405 Talence Cedex, France
}

Electronic Supplementary Information (ESI) available: [details of any supplementary information available should be included here]. See DOI: $10.1039 / \times 0 \times x 00000 x$ a fluorenyl terpyridine ligand and demonstrated their phototoxicity and photobactericidal capabilities in correlation with NO delivery. ${ }^{10}$ In our former investigations, we also studied a series of Ru-nitrosyl complexes with substituted terpyridine (tpy) ligands on the $4^{\prime}$ position, bearing electron-donating or electron withdrawing groups. We planned to find out whether these substituents had any influence on the $\mathrm{Ru}(\mathrm{NO}) / \mathrm{Ru}(\mathrm{ON})$ photoisomerization and on the NO photorelease. ${ }^{11,12}$ In addition, DFT calculations were carried out to elucidate the mechanism of release. ${ }^{13}$ Similarly, this particular study focuses on the two cis/trans- $(\mathrm{Cl}, \mathrm{Cl})-\left[\mathrm{Ru}(\mathrm{R}-\mathrm{Phtpy}) \mathrm{Cl}_{2}(\mathrm{NO})\right]^{+}$ isomers with $\mathrm{NEt}_{2}$ as $\mathrm{R}$ on the $4^{\prime}$-position of the Phtpy (Scheme1). This strong electron-donating substituent was chosen from the expectation of a better efficiency in the NO release process by virtue of an enhanced "push-pull» effect towards the electronwithdrawing NO ligand. In addition, DFT calculations suggest a shift of the absorption of the cis/trans- $(\mathrm{Cl}, \mathrm{Cl})-\left[\mathrm{Ru}(\mathrm{R}-\mathrm{Phtpy}) \mathrm{Cl}_{2}(\mathrm{NO})\right]^{+}$ complexes to longer wavelengths. It is important for biological applications that the molecules are activated by less energetic irradiation, as it avoids deleterious effects of UV irradiation. ${ }^{14}$ This paper describes the synthesis of the ruthenium-nitrosyl complexes with diethylanilineterpyridyl-based ligands which leads to three different final compounds with various NO releasing efficiencies. In addition, the structures of three ruthenium-nitrosyl complexes and one of a photoproduct are solved by X-ray diffraction.

\section{Results and discussion}

\section{Synthesis}

As previously reported, the preparation of ruthenium-nitrosyl complexes with tpy ligands can be carried out by using $\mathrm{K}_{2}\left[\mathrm{RuCl}_{5} \mathrm{NO}\right]$ which already includes the nitrosyl ligand. Unfortunately, most of 
the time, the main product is the homoleptic complex with two tpy ligands around the metal ion. ${ }^{11}$ However, in the synthesis of complexes 1 , by adding $\mathrm{K}_{2}\left[\mathrm{RuCl}_{5} \mathrm{NO}\right]$ in small portions to the solution of the ligand, we were able to decrease the proportion of homoleptic complex and obtained the trans isomer as the major compound (Fig. S1, ESI). Another way is to bubble NO gas on the starting complex [R-tpyRuCl 3 ]: only the cis and trans isomers are formed with the trans one as major compound. ${ }^{12}$ Thus, by bubbling $\mathrm{NO}$ on the starting compound $\left[\mathrm{NEt}_{2}-\mathrm{Ph} \text {-tpyRuCl}\right]_{3}$, we obtained two series of complexes: i) the cis/trans- $(\mathrm{Cl}, \mathrm{Cl})-\left[\mathrm{Ru}\left(\mathrm{NEt}_{2}-\mathrm{Phtpy}_{\mathrm{Cl}} \mathrm{Cl}_{2}(\mathrm{NO})\right]^{+}\right.$ (as expected) and ii) the cis/trans-( $\mathrm{Cl}, \mathrm{Cl})$-complexes with a modified Phtpy on the amine function (see Scheme 1).

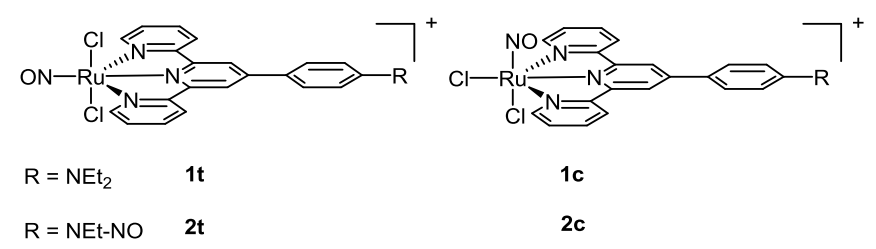

Scheme 1: Structure of the studied compounds.

In the last case, as NO is in excess, in the presence of air, it can react with the tertiary amine function on the phenyl ring and leads to the corresponding nitrosamine as highlighted by $\mathrm{X}$-ray analysis of a crystal of trans-(Cl,Cl)-[Ru(NEt(NO)-Phtpy) $\left.\mathrm{Cl}_{2}(\mathrm{NO})\right]\left(\mathrm{PF}_{6}\right) \quad[\mathbf{2 t}]^{+}\left(\mathrm{PF}_{6}\right)$ (vide infra). ${ }^{1} \mathrm{H}$ NMR spectroscopy is in accordance with this structure: the aliphatic protons are largely deshielded and the peaks area integrations for these protons are consistent with five protons and confirm the presence of a single ethyl chain on the amine function. In order to obtain the mixture of $[\mathbf{1 t}]^{+}$and $[\mathbf{1} \mathbf{c}]^{+}$by this method, we have to carefully bubble argon to eliminate any trace of NO before opening the flask for further work-up (see experimental part). In fact, $[\mathbf{1 t}]^{+}$can be obtained as a pure compound whereas $[\mathbf{1} \mathbf{c}]^{+}$is always isolated with some $[\mathbf{2 c}]^{+}$(around $10 \%)$ even after separation by HPLC. In order to obtain $[\mathbf{1 c}]^{+}$as a pure compound, we had to use the other synthetic route, the one with $\mathrm{K}_{2}\left[\mathrm{RuCl}_{5} \mathrm{NO}\right]$. As it is well known, $\mathrm{N}$-nitrosamines are found in many foods due to the use of nitrite to prevent the growth of Clostridium botulinum. ${ }^{15}$ They are formed by reaction of organic amines with nitrosating agents. ${ }^{16}$ In fact, free NO is a poor nitrosating agent and becomes powerful when oxidized by molecular oxygen. ${ }^{17}$ This is in line with our observations: the nitrosamine formation leading to [2] ${ }^{+}$is only obtained when $\mathrm{NO}$ and air are present together in the reaction flask. Most of the reactions described in the literature deal with $\mathrm{N}$-nitrosamines formation from secondary amines. ${ }^{18}$

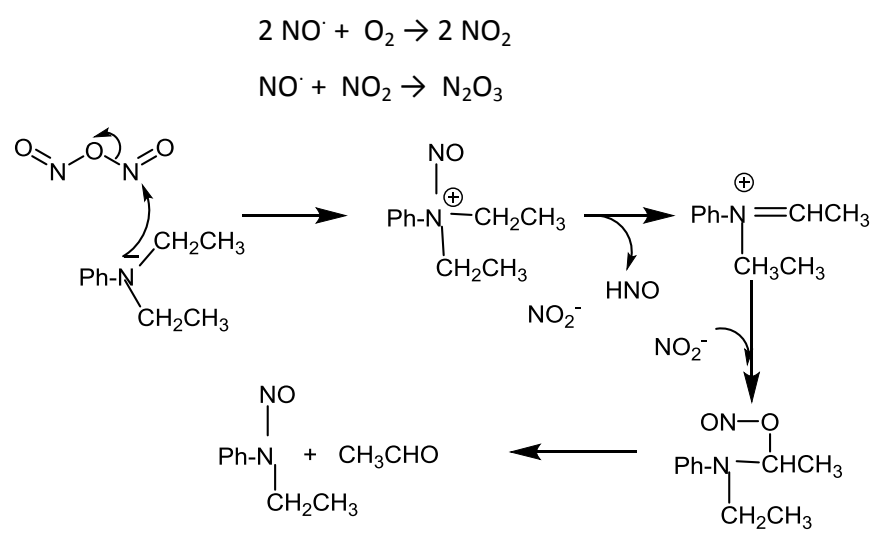

2 | J. Name., 2012, 00, 1-3
Scheme 2: Tentative mechanism for the formation of N-nitrosamine.

In our case, the reaction took place on a tertiary amine. ${ }^{19} \mathrm{~A}$ tentative mechanism is proposed (Scheme 2), based on literature. $^{17,19}$ Favourable factors are brought together to yield nitrosamine: warming (the reaction is carried out at $80^{\circ} \mathrm{C}$ ), dipolar solvent (DMF) and decrease of the basicity of the amine function (due to the electro-attractive character of the nitrosyl ligand). In fact, in our previous syntheses such an effect was nor observed as no function sensitive to oxidation was available. ${ }^{12}$ It is reported that there might be a parallel pathway to nitrosamine formation in which the cation radical partitions between $\mathrm{C}$-nitro and $\mathrm{N}$-nitroso products. ${ }^{17}$ In the present case, we only obtained the $\mathrm{N}$-nitroso compound and the $\mathrm{C}$-nitro derivative was obtained by another way, with concentrated nitric acid (vide infra). Full characterization will be presented only for complexes $[\mathbf{1}]^{+}$and $[\mathbf{2 t}]^{+}$as $[\mathbf{2} \mathbf{c}]^{+}$was obtained in such a small amount that it did not allow extensive study.

In order to check if the dialkylaniline substituent on trans- $(\mathrm{Cl}, \mathrm{Cl})$ $\left[\mathrm{Ru}\left(\mathrm{NEt}_{2}-\mathrm{Phtpy}\right) \mathrm{Cl}_{2}(\mathrm{NO})\right]^{+}\left(\mathrm{PF}_{6}\right)[\mathbf{1}]^{+}\left(\mathrm{PF}_{6}\right)$ could be protonated, we added one drop of concentrated nitric acid $(65 \%)$ on a solution of $[\mathbf{1 t}]^{+}\left(\mathrm{PF}_{6}\right)$ in acetonitrile, at room temperature, and we observed an instantaneous loss of the dark-blue colour which progressively became orange; by diffusion of diethyloxide in this solution, we obtained crystals for which the structure of $[3 \mathbf{t}]^{+}\left(\mathrm{PF}_{6}\right)$ was determined by $\mathrm{X}$-ray diffraction. It revealed that the Phtpy moiety was modified by a nitration on the phenyl ring. By reproducing the experiment on a larger quantity of complex (see S1), we could obtain some amount of the resulting complex $[3 \mathrm{t}]^{+}\left(\mathrm{PF}_{6}\right)$ for which ${ }^{1} \mathrm{H}$ NMR was recorded. The spectrum showed that compound $[3 \mathrm{t}]^{+}\left(\mathrm{PF}_{6}\right)$ was fairly pure and was in accordance with the X-ray structure. We could identify only three aromatic protons belonging to the phenyl ring (instead of four protons in the starting compound) with coupling constants consistent with an AMX system (Fig. S2, ESI). Nitration in so mild conditions on a derivative of a tpy ligand is surprising as strong acidic medium and heating are usually required. It has been described in the literature that nitration in organic solvents can proceed with nitric acid in large excess. ${ }^{20}$ The nitronium ion formed by heterolysis of nitric acid as being the active reagent in solution, is under discussion. The $\mathrm{NEt}_{2}$ substituent favours nitration on the ortho-position due to stabilization of the resonance forms by its lone-pair (para-position is not available) as usually described for anilines and as observed in the present case. This particular reactivity of the aromatic ring of the Phtpy is probably due to the fact that the Phtpy ligand is engaged in the coordination of the ruthenium atom. Moreover, it is noticed that the nitration occurred on the phenyl ring and not on the pyridine rings. The same experiment was carried out on the free ligand $\mathrm{NEt}_{2}$ Phtpy and did not lead to any modification of the starting material. This observation is in line with some part of the literature: it has been fully reported that some reactions can be carried out on complexes more easily and/or more specifically than on free ligands. $^{21}$ 


\section{UV-Visible spectroscopy and DFT analysis}

The UV-Visible spectra of the ligand $\mathrm{NEt}_{2} \mathrm{Phtpy},[\mathbf{1 t}]^{+}\left(\mathrm{PF}_{6}\right),[1 \mathrm{c}]^{+}\left(\mathrm{PF}_{6}\right)$ and $[\mathbf{2 t}]^{+}\left(\mathrm{PF}_{6}\right)$ in acetonitrile are shown in Fig. 1 and the main main bands with similar intensities but at lower energies; (ii) the visible band located around $550 \mathrm{~nm}$ is blue-shifted for $[\mathbf{1 c}]^{+}\left(\mathrm{PF}_{6}\right)$; (iii) the main bands of $[\mathbf{2 t}]^{+}\left(\mathrm{PF}_{6}\right)$ are blue-shifted compared to $[\mathbf{1 t}]^{+}\left(\mathrm{PF}_{6}\right)$;

$\begin{array}{lllllll} & \text { Experimental data } & \text { Transition } & \lambda_{\max } & f & \text { Composition } & \text { Character } \\ \text { Compound } & \lambda(\mathrm{nm})\left(\varepsilon\left(\mathrm{M}^{-1} \mathrm{~cm}^{-1}\right)\right) & & (\mathrm{nm}) & \end{array}$

\begin{tabular}{|c|c|c|c|c|c|c|}
\hline & $356(22000)$ & $1 \rightarrow 3$ & 363 & 0.554 & $99 \% \chi_{101 \rightarrow 103}$ & aniline $\rightarrow$ tpy \\
\hline \multirow[t]{3}{*}{$\mathrm{NEt}_{2}$ Phtpy } & $290(22500)$ & $1 \rightarrow 4$ & 289 & 0.319 & $93 \% \chi_{100 \rightarrow 103}$ & tpy $\rightarrow$ tpy \\
\hline & $278(21800$ & $1 \rightarrow 9$ & 276 & 0.459 & $78 \% \chi_{100 \rightarrow 102}$ & tpy $+\varepsilon$ aniline $\rightarrow$ tpy \\
\hline & & & & & $+14 \% \chi_{101 \rightarrow 106}$ & \\
\hline \multirow[t]{5}{*}{ 1c } & $516(17200)$ & $1 \rightarrow 3$ & 632 & 0.242 & $88 \% \chi_{133 \rightarrow 134}$ & aniline $\rightarrow$ Ru(NO) \\
\hline & & & & & $+10 \% \chi_{133 \rightarrow 135}$ & \\
\hline & $350(14500)$ & $1 \rightarrow 4$ & 487 & 0.359 & $99 \% \chi_{133 \rightarrow 136}$ & aniline $\rightarrow \mathrm{Ru}(\mathrm{NO})+\varepsilon$ tpy \\
\hline & $320(21100)$ & & & & & \\
\hline & $300(23300)$ & & & & & \\
\hline \multirow[t]{4}{*}{$1 t$} & $550(20200)$ & $1 \rightarrow 2$ & 656 & 0.403 & $100 \% \chi_{133 \rightarrow 134}$ & aniline $\rightarrow \mathrm{Ru}(\mathrm{NO})$ \\
\hline & $347(12600)$ & $1 \rightarrow 7$ & 460 & 0.280 & $99 \% \chi_{133 \rightarrow 136}$ & aniline $\rightarrow \mathrm{Ru}(\mathrm{NO})+$ tpy \\
\hline & $322(17400)$ & & & & & \\
\hline & $301(18600)$ & & & & & \\
\hline \multirow[t]{4}{*}{$2 t$} & $497(3200)$ & & & & & \\
\hline & $357(17200)$ & $1 \rightarrow 4$ & 457 & 0.323 & $98 \% \chi_{132 \rightarrow 133}$ & ON-N-ph $\rightarrow$ Ru(NO) \\
\hline & $299(18600)$ & $1 \rightarrow 12$ & 373 & 0.071 & $81 \% \chi_{129 \rightarrow 133}$ & tpy $\rightarrow \mathrm{Ru}(\mathrm{NO})$ \\
\hline & $277(19700)$ & $1 \rightarrow 16$ & 349 & 0.268 & $92 \% \chi_{132 \rightarrow 135}$ & ON-N-ph $\rightarrow \mathrm{Ru}(\mathrm{NO})+\mathrm{tpy}$ \\
\hline 4 & $\approx 1000(\approx 2400)$ & $1 \rightarrow 4$ & 1241 & 0.166 & $88 \% \chi_{136 \rightarrow 137}$ & $\mathrm{RuCl}_{2} \rightarrow$ aniline \\
\hline \multirow[t]{3}{*}{ (photoproduct) } & $490(17000)$ & $1 \rightarrow 9$ & 477 & 0.457 & $44 \% \chi_{136 \rightarrow 138}$ & aniline $+\mathrm{RuCl}_{2} \rightarrow$ tpy \\
\hline & & & & & $+41 \% \chi_{137 \rightarrow 138}$ & \\
\hline & $\begin{array}{l}420(11000) \\
318(24600)\end{array}$ & & & & & \\
\hline
\end{tabular}

Table 1 : Experimental and computational (DFT) data for the tpy ligand and the related complexes.

spectroscopic data are gathered in Table 1 . The spectrum of the ligand consists in two main bands located in the $270-400 \mathrm{~nm}$ range, arising from two main components ( $\lambda_{\max }$ at 290 and $356 \mathrm{~nm}$ ) and exhibits extinction coefficients $(\varepsilon)$ of about $22000 \mathrm{~mol}^{-1} \mathrm{~L} \mathrm{~cm}^{-1}$.

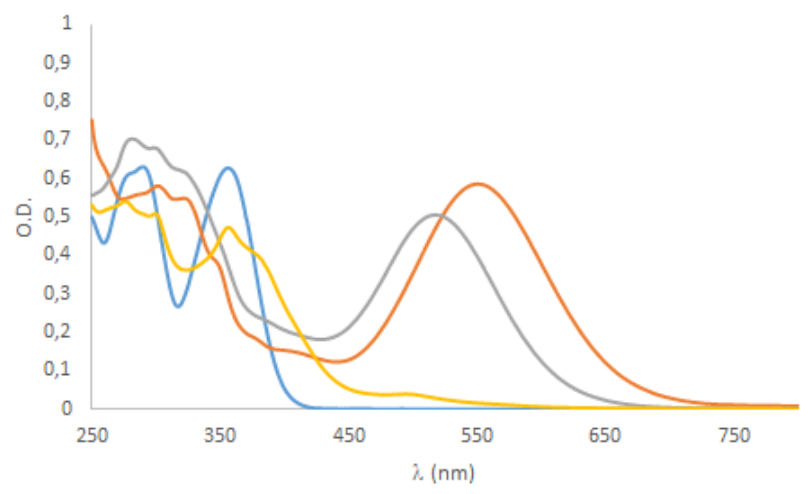

Fig. 1: Electronic spectra of the ligand (blue) and the three complexes in acetonitrile: $[\mathbf{1 t}]^{+}\left(\mathrm{PF}_{6}\right)$ orange), $[\mathbf{1}]^{+}\left(\mathrm{PF}_{6}\right)$ (grey) and $[\mathbf{2 t}]^{+}\left(\mathrm{PF}_{6}\right)$ (yellow).

The main features of the spectra of the ruthenium complexes can be resumed as followed: (i) $[\mathbf{1 t}]^{+}\left(\mathrm{PF}_{6}\right)$ and $[\mathbf{1}]^{+}\left(\mathrm{PF}_{6}\right)$ show two

(iv) additional transitions of lower intensities are present as shoulders between the main bands.

As predicted, visible to the naked eye, a strong bathochromic shift is observed for complexes 1 . This suggests that NO-release on this series could be carried out by visible irradiation. By contrast, the colour of complex $[\mathbf{2 t}]^{+}\left(\mathrm{PF}_{6}\right)$ bearing the nitrosamine substituent, is similar to the previously prepared compounds ${ }^{12}$ as the electrondonating property of the NONEt substituent is decreased compared to $\mathrm{NEt}_{2}$.

The DFT computed data are gathered in Table 1 and compared with the data extracted from the UV-visible spectra. In the case of the ligand, the agreement appears excellent between theory and experiment, with the low energy transition exhibiting net aniline to tpy charge transfer character. On the other hand, there are some discrepancies for the ruthenium nitrosyl complexes $[\mathbf{1 c}]^{+},[\mathbf{1} t]^{+}$, and $[2 \mathrm{t}]^{+}$. Here there are energy differences of about $0.4 \mathrm{eV}$ between the experimental and theoretical low lying transition. Although significant, this difference is still acceptable, taking into account the presence of heavy atom (ruthenium), large molecular size and intense charge transfer character. ${ }^{22}$ The lowest transition energies in the trans $(\mathrm{Cl}, \mathrm{Cl})$ vs $\operatorname{cis}(\mathrm{Cl}, \mathrm{Cl})$ observed by UV-visible spectroscopy $\left(1200 \mathrm{~cm}^{-1}\right.$ in $[\mathbf{1 t}]^{+}$vs $[\mathbf{1 c}]^{+}$in Table 1$)$ are observed also computationally, but to a less extent compared to those at $580 \mathrm{~cm}^{-}$ 
${ }^{1}$. In both cases, the HOMO (133) to LUMO (134) excitation brings the major contribution to this transition arising from a sizeable aniline to $\mathrm{Ru}(\mathrm{NO})$ charge transfer effect.

\section{X-ray analysis}

Crystals of complexes $[\mathbf{1 c}]^{+}$and $[\mathbf{2 t}]^{+}$and $[\mathbf{3 t}]^{+}$allowed to elucidate their structures by X-ray diffraction. Selected bonds are depicted in Table 2 and crystal data are given in Tables S2-S4.

Table 2: Selected bonds for complexes [1c], [1t $]^{+},[\mathbf{2 t}]^{+}$and $[\mathbf{3 t}]^{+}$

\begin{tabular}{lllll}
\hline $\begin{array}{l}\text { Selected } \\
\text { bonds }(\AA)\end{array}$ & {$[\mathbf{1} \mathbf{c}]^{+}$} & {$[\mathbf{1 t}]^{+11}$} & {$[\mathbf{2 t}]^{+}$} & {$[\mathbf{3 t}]^{+}$} \\
\hline Ru-N(1) & $1.836(8)$ & $1.762(10)$ & $1.752(2)$ & $1.764(2)$ \\
Ru-N(2) & $2.075(7)$ & $2.081(5)$ & $2.085(2)$ & $2.079(2)$ \\
Ru-N(3) & $1.964(6)$ & $1.988(5)$ & $2.0089(19)$ & $2.001(2)$ \\
Ru-N(4) & $2.090(7)$ & $2.089(5)$ & $2.077(2)$ & $2.076(2)$ \\
Ru-Cl(1) & $2.319(2)$ & $2.3197(19)$ & $2.3533(7)$ & $2.3422(11)$ \\
Ru-Cl(2) & $2.403(2)$ & $2.305(3)$ & $2.3641(7)$ & $2.3652(11)$ \\
N(1)-O & $1.055(10)$ & $1.017(12)$ & $1.237(3)$ & $1.131(3)$ \\
N(5)-C(19) & $1.384(12)$ & $1.373(7)$ & $1.423(3)$ & $1.380(12)$
\end{tabular}

In $[\mathbf{1 c}]^{+}$, one ethyl group was disordered over two positions in $68: 32$ ratio. By comparing the bond lengths between the ruthenium atom and the nitrosyl ligand in $[\mathbf{1 c}]^{+}$and $[\mathbf{1} t]^{+}$, we can notice that Ru-N(1) bond length is longer in the cis isomer and that it is similar in the three trans isomers, indicating no influence of the electron-donating ability of the tpy substituent. However, a characteristic difference, because of the strong $\pi$-acceptor character of the nitrosyl ligand is observed. The $\mathrm{N}-\mathrm{O}$ distance in $[1 \mathrm{c}]^{+}(1.055(10) \AA)$ is greater than that of $[\mathbf{1 t}]^{+}(1.017(12) \AA)$ because of the weak $\pi$-donor and the $\sigma$-donor characters of the chlorido ligand compared to the $\pi$-acceptor character of the py ligand, as previously reported by $\mathrm{Coe}^{23}$ and observed by Nagao. ${ }^{24}$ Moreover, we notice that the nitrosyl ligand is slightly bent in [1c $]^{+}$(angle Ru$\mathrm{N}-\mathrm{O}=163.7(9)^{\circ}$ ) in comparison with the other trans isomers (angle Ru-N-O $175.5(2)$ to $\left.177.8(2)^{\circ}\right)$. The Ru-N distance to the linear nitrosyl $(\approx 1.76 \AA)$ in the trans isomers, is significantly shorter than that to the slightly bent nitrosyl $(1.836(8) \AA)$ in [1c] ${ }^{+}$, suggesting the greater $\pi$-back donation to the linear nitrosyl. Besides, in the coordination sphere of the ruthenium atom, the next shortest bond is the one between the metal ion and the central pyridine $N(3)$ with both bonds being trans to a chlorido ligand.

Regarding complexes $[\mathbf{2 t}]^{+}$and $[\mathbf{3 t}]^{+}$, both include a withdrawing group on the phenyl ring: a nitrosamine in $[\mathbf{2 t}]^{+}$and a nitro group in $[3 t]^{+}$. The geometries around the metal ion are very similar for both structures. The main differences are related to the $\mathrm{N}-\mathrm{O}$ bond length which is the longest in $[\mathbf{2 t}]^{+}$, in which the deactivation occurs directly on the amine group with NONEt as substituent instead of $\mathrm{NEt}_{2}$ in $[\mathbf{1 t}]^{+}$. In fact, given that in $[\mathbf{3 t}]^{+}$, the $\mathrm{NO}_{2}$ withdrawing group is on the phenyl ring in ortho position to the $\mathrm{NEt}_{2}$ function, it seems to have less influence on the $\mathrm{N}-\mathrm{O}$ bond length. The same observation may be drawn by examining the $N(5)-C(19)$ bond length which is longer for $[\mathbf{2 t}]^{+}$. For the latter, the mesomeric form is disfavoured due to the nitrogen doublet, but it could have a contribution in the three other complexes.
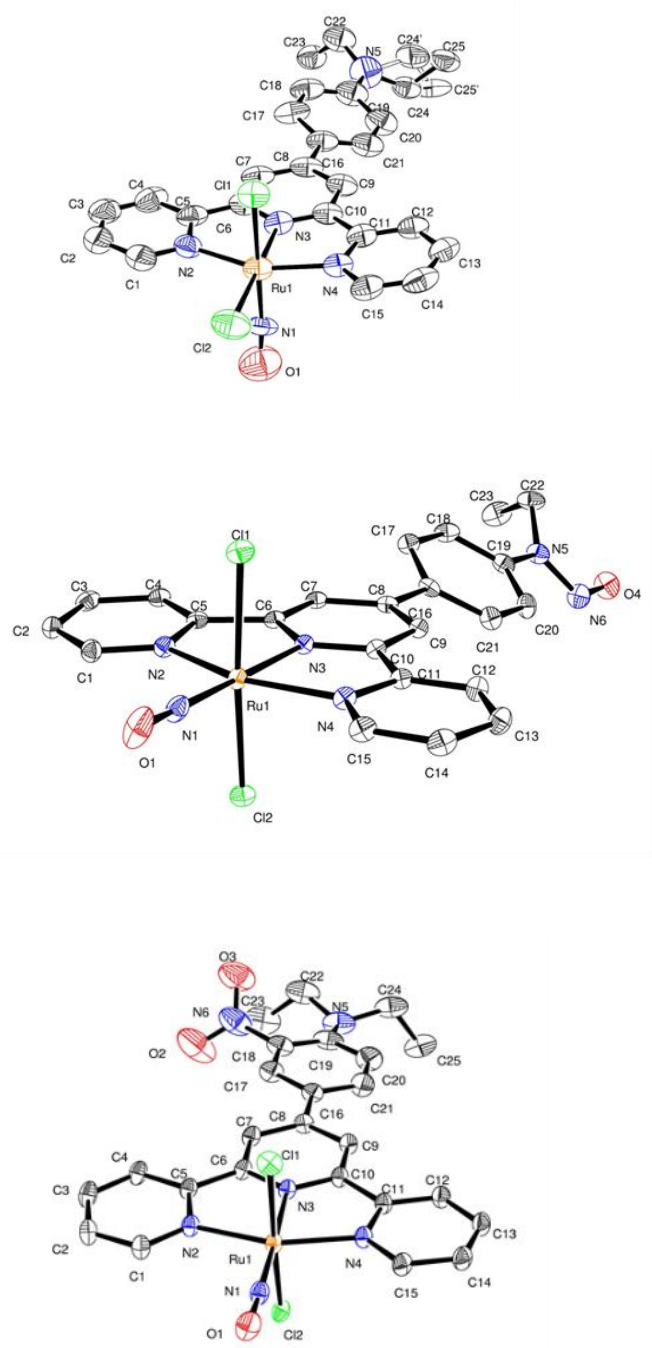

Fig. 2: Molecular structures of $[\mathbf{1 c}]^{+}\left(\right.$upper), $[\mathbf{2 t}]^{+}$(middle) and $[\mathbf{3 t}]^{+}($down). Displacement ellipsoids are drawn at 50\% probability level. Hydrogen atoms are omitted for clarity.

\section{Electrochemistry}

Cyclic voltammetry (CV) experiments were conducted on $1 \mathrm{M}$ solutions of the three complexes in MeCN (Fig. 3 for complexes $[\mathbf{1 t}]^{+}\left(\mathrm{PF}_{6}\right)$ and $[\mathbf{1 c}]^{+}\left(\mathrm{PF}_{6}\right)$ and Fig. S3, ESI for complex $\left.[\mathbf{2 t}]^{+}\left(\mathrm{PF}_{6}\right)\right)$. The cyclic voltammograms reveal multiple couples resulting from redox processes centred at the metal, the nitrosyl ligand and the tpy ligand.

On the starting complexes $[\mathbf{1 t}]^{+}\left(\mathrm{PF}_{6}\right)$ and $[\mathbf{1} \mathbf{c}]^{+}\left(\mathrm{PF}_{6}\right)$ before irradiation, three reduction peaks are observed (Fig. 3): the one at the more positive value is reversible and the two others are irreversible at the $\mathrm{CV}$ time scale; the first reduction corresponds to the Ru- $\mathrm{NO}^{+}$/ process, according to previous reported studies on polypyridine $\mathrm{Ru}^{\prime \prime}(\mathrm{NO})$ systems. ${ }^{12,25}$ The nitrosyl based reductions 
involving Ru-NO ${ }^{+} / \mathrm{NO}$ and $\mathrm{Ru}-\mathrm{NO} / \mathrm{NO}^{-}$conversions appear at -0.15 $\mathrm{V}$ and $-0.24 \mathrm{~V}$ (reversible) and $-0.47 \mathrm{~V}$ and $-0.57 \mathrm{~V}$ (irreversible) versus SCE for $[\mathbf{1}]^{+}\left(\mathrm{PF}_{6}\right)$ and $[\mathbf{1 t}]^{+}\left(\mathrm{PF}_{6}\right)$ respectively. We can notice that $[1 \mathbf{c}]^{+}\left(\mathrm{PF}_{6}\right)$, in which the Ru-NO bond is trans to a chlorido, is more easily reduced as previously observed. ${ }^{12}$
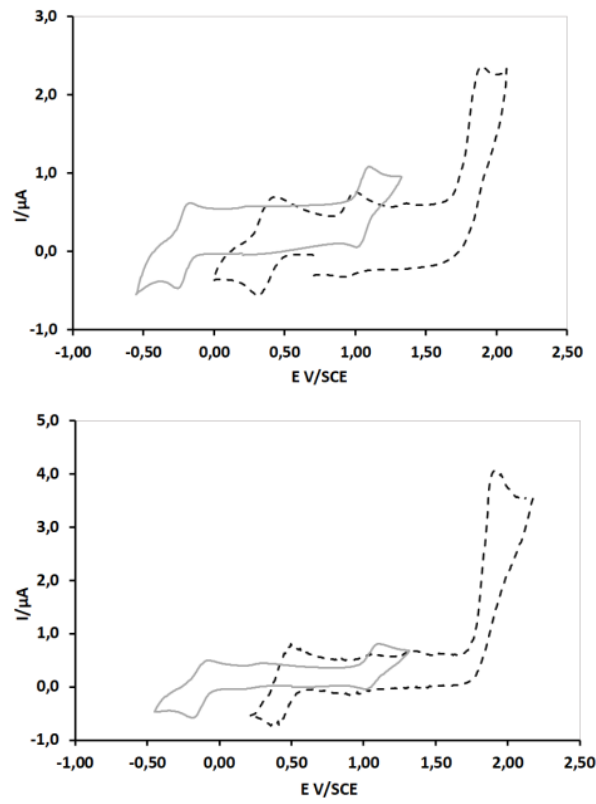

Fig 3: Cyclic voltammograms of $[\mathbf{1 t}]^{+}\left(\mathrm{PF}_{6}\right)$ (upper) and $[\mathbf{1}]^{+}\left(\mathrm{PF}_{6}\right)$ (down) before ( ) and after(---) irradiation with a Xenon lamp, $1 \mathrm{mM}$ in MeCN,

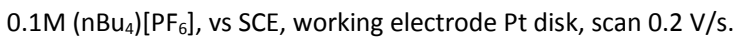

The Ru- $\mathrm{NO}^{+} /$peak potential is sensitive to the nature of the tpy ligand and more particularly to the substituents on the 4'-position, $\mathrm{NEt}_{2}$ or NONEt, as it can be inferred from values in Table 3 . The $\mathrm{NEt}_{2}$ substituent is electron-donating and the reduction of the corresponding Ru- $\mathrm{NO}^{+} /$in $[\mathbf{1 t}]^{+}\left(\mathrm{PF}_{6}\right)$ is more difficult compared to that of complex $[\mathbf{2 t}]^{+}\left(\mathrm{PF}_{6}\right)$ with NONEt, which is less electrondonating. In fact, in the trans isomers the Phtpy affects the nitrosyl ligand due to its position, as there is an effective electronic transfer from the Phtpy ligand to the NO.

Table 3: Values of the waves measured by cyclic voltammetry (V)

\begin{tabular}{|c|c|c|c|}
\hline \multirow[t]{2}{*}{ Compound } & \multicolumn{2}{|c|}{ Before irradiation } & \multirow{2}{*}{$\begin{array}{c}\text { After irradiation } \\
\mathrm{Ru}^{\mathrm{b}} / \mathrm{Ru}\end{array}$} \\
\hline & $\mathrm{Ru}-\mathrm{NO}^{+} / \mathrm{Ru}-\mathrm{NO}$ & Red $^{a}$ & \\
\hline$[\mathbf{1 t}]^{+}\left(\mathrm{PF}_{6}\right)$ & -0.24 & $-0.57 ;-1.31$ & 0.37 \\
\hline$[1 \mathrm{c}]^{+}\left(\mathrm{PF}_{6}\right)$ & -0.15 & $-0.47 ;-1.27$ & 0.40 \\
\hline$[2 \mathbf{t}]^{+}\left(\mathrm{PF}_{6}\right)$ & -0.13 & $-0.65 ;-1.18$ & 0.41 \\
\hline
\end{tabular}

Complex $1 \mathrm{mM}$ in $\mathrm{MeCN}, 0.1 \mathrm{M}\left(\mathrm{nBu}_{4}\right)\left[\mathrm{PF}_{6}\right]$, vs SCE, working electrode Pt disk, scan $0.2 \mathrm{~V} / \mathrm{s}$; (a) irreversible waves (b) with a Xenon lamp for two hours

Under irradiation the voltammograms of the resulting complexes appear deeply different: disappearance of the two reduction waves ascribed to $\mathrm{Ru}-\mathrm{NO}^{+} /$and $\mathrm{Ru}-\mathrm{NO} /$ processes that indicate complete NO release and appearance of a fully reversible reduction wave at $\approx$ $0.40 \mathrm{~V}$ attributed to the $\mathrm{Ru} / \mathrm{III} / \mathrm{Ru}^{\prime \prime}$ couple. ${ }^{26}$

An oxidation wave at $\approx 1 \mathrm{~V} / \mathrm{SCE}$ observed in the ligand (Fig. S4, ESI) and in the complexes $[\mathbf{1}]^{+}\left(\mathrm{PF}_{6}\right)$ before and after irradiation could be attributed to the oxidation of $\mathrm{NEt}_{2}$ group of the tpy ligand. ${ }^{27}$ Its value is slightly lower in the free ligand $(0.84 \mathrm{~V})$ in comparison with the values measured on the complexes ( 0.96 to $1.06 \mathrm{~V}$ ) indicating that once the ligand is engaged in coordination, the metal ion depletes electron density on the tpy ligand and its substituent.

\section{Photochemical properties}

The complexes $[\mathbf{1}]^{+}\left(\mathrm{PF}_{6}\right)$ and $[\mathbf{2 t}]^{+}\left(\mathrm{PF}_{6}\right)$ were found to be stable in acetonitrile solutions at room temperature when protected from the light. On exposure to light, photo-labilization of NO led to the respective solvate species.

The overall photochemical process can be represented by equation (1):

$$
\left[(\mathrm{L}) \mathrm{Ru}^{\prime \prime}-\mathrm{NO}^{+}\right]+\text {solvent } \stackrel{\boldsymbol{h} \boldsymbol{v}}{\rightarrow}\left[(\mathrm{L}) \mathrm{Ru}^{\prime \prime \prime} \text {-solvent }\right]+\mathrm{NO}^{\bullet}
$$

Under monochromatic continuous irradiation and assuming that the reacting solution is homogeneous, the evolution of the reactant concentration $\left[\mathrm{Ru}^{\prime \prime}\right]$ is given by equation (2):

$\mathrm{d}\left[\mathrm{Ru} \mathrm{u}^{\mathrm{II}}\right] / \mathrm{dt}=-\Phi \varepsilon_{\text {Rull }} \mathrm{I}\left[\mathrm{Ru} \mathrm{u}^{\prime \prime}\right] \mathrm{I}_{0} \mathrm{~F} \quad(2)^{28}$

where $F$ stands for the photokinetic factor: $F=\left(1-10^{-A b s}\right) /$ Abs with Abs $=\left(\varepsilon_{\text {RuIl }}\left[R u^{\text {II }}\right]+\varepsilon_{\text {Rull }}\left[R u^{\text {III }}\right]\right)$ I. $\Phi$ is the photochemical quantum yield, $I_{0}$ is the incident photon flux (in M. $\mathrm{s}^{-1}$ ), $\varepsilon_{\text {Rull }}$ (in $\mathrm{M}^{-1} . \mathrm{cm}^{-1}$ ) is the molar extinction coefficient of the ruthenium nitrosyl complexes and I (in $\mathrm{cm}$ ) is the length of the optical irradiation path. The values of the quantum yield and extinction coefficients of the $\mathrm{Ru}^{\text {III }}$ species are obtained by fitting of the model on two experimental wavelengths, the irradiation wavelength (365 nm) and an observation wavelength $\left(\lambda_{\text {obs }}\right)$ chosen for its significant amplitude variation during irradiation. All experiments could be reproduced with a good accuracy.

On exposure to irradiation with a $\mathrm{Hg} \operatorname{lamp}\left(\lambda_{\text {irr }}=365 \mathrm{~nm}\right)$ the acetonitrile solution of $[\mathbf{1} \mathbf{c}]^{+}\left(\mathrm{PF}_{6}\right)$ or $[\mathbf{1 t}]^{+}\left(\mathrm{PF}_{6}\right)$ (cis or $\operatorname{trans}(\mathrm{Cl}, \mathrm{Cl})$ $\left.\left[\mathrm{Ru}\left(\mathrm{NEt}_{2}-\mathrm{Ph}\right) \mathrm{Cl}_{2}(\mathrm{NO})\right]\left(\mathrm{PF}_{6}\right)\right)$ undergo a colour change from dark-blue for $[\mathbf{1 t}]^{+}\left(\mathrm{PF}_{6}\right)$, or dark-red for $[\mathbf{1 c}]^{+}\left(\mathrm{PF}_{6}\right)$ to orange over a period of 75 $\min$.
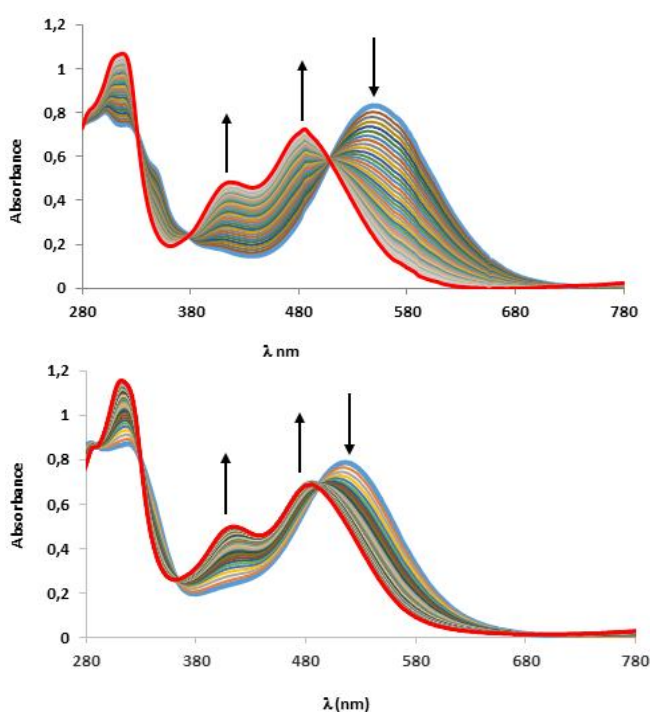

Fig.4: Time evolution of the electronic spectra of $\left.[\mathbf{1}]^{+}\right]^{+}\left(\mathrm{PF}_{6}\right)$ (upper) and $[\mathbf{1 C}]^{+}\left(\mathrm{PF}_{6}\right)$ (down) under irradiation at $365 \mathrm{~nm}$ in MeCN at 293K. 
The progression of the photocleavage of the Ru-NO bond was monitored spectrophotometrically: the intensities of the peaks at 550 and $516 \mathrm{~nm}$ for $[\mathbf{1 t}]^{+}\left(\mathrm{PF}_{6}\right)$ and $[\mathbf{1 c}]^{+}\left(\mathrm{PF}_{6}\right)$ respectively, decrease while some new peaks appear at $\lambda \approx 485$ and $415 \mathrm{~nm}$ (Fig. 4). The presence of isobestic points $(331,376,507$ and $494 \mathrm{~nm}$ respectively for $[\mathbf{1 t}]^{+}\left(\mathrm{PF}_{6}\right.$ and $\left.[\mathbf{1 c}]^{+}\left(\mathrm{PF}_{6}\right)\right)$ suggests the direct transformation of $\left[\mathrm{Ru}\left(\mathrm{NEt}_{2}-\mathrm{Phtpy}\right) \mathrm{Cl}_{2}(\mathrm{NO})\right]\left(\mathrm{PF}_{6}\right)$ to the corresponding solvate species. ${ }^{25,12}$ Hence, facile photo-induced $N O$ release by $[\mathbf{1 t}]^{+}\left(\mathrm{PF}_{6}\right)$ and $[\mathbf{1 c}]^{+}\left(\mathrm{PF}_{6}\right)$ under standard (one-photon) excitation at $365 \mathrm{~nm}$ was demonstrated, leading to NO release quantum yield values gathered in Table 4. The same experiment was carried out on complex $[2 \mathrm{t}]^{+}\left(\mathrm{PF}_{6}\right)$ and led to the photoproduct after $45 \mathrm{~min}$ of irradiation (Fig. S5, ESI). In comparing $[\mathbf{1 t}]^{+}\left(\mathrm{PF}_{6}\right)$ and $[\mathbf{2 t}]^{+}\left(\mathrm{PF}_{6}\right)$, it is noted that $[\mathbf{2 t}]^{+}\left(\mathrm{PF}_{6}\right)$ is more efficient in NO release, indicating influence of the electron-donating nature of the substituent on the 4' position as follows: more donating substituents lead to less powerful NO-donors as we reported on a series of Ru-nitrosyl complexes. $^{12}$

We also noticed a better photoreactivity of the cis isomer $[\mathbf{1 c}]^{+}\left(\mathrm{PF}_{6}\right){ }^{12}$ TD-DFT and DFT investigations of the excited states involved in the photolytic cleavage of the Ru-NO bond have highlighted the crucial role of a metastable state also known as the MS2 isomer. ${ }^{13}$ In the ground state, the NO ligand is bound to the ruthenium atom through $\mathrm{N}$, while the metastable isonitrosyl isomer termed MS1 is bound through $\mathrm{O}$, and the sideways-bound isomer is denoted MS2. Alary et al. suggest that differences in photoreactivity between cis and trans isomers may be linked to the different absorption properties shown by the sideways-bound isomer MS2 that is involved in the absorption of a second photon.

Table 4: Quantum yields of NO release with irradiation at $365 \mathrm{~nm}(546 \mathrm{~nm})$.

\begin{tabular}{ccc}
\hline Compound & $\Phi_{\mathrm{NO}}$ trans isomers & $\Phi_{\mathrm{NO}}$ cis isomers \\
\hline$[1]^{+}\left(\mathrm{PF}_{6}\right)$ & $0.09(0.01)$ & $0.12(0.045)$ \\
{$[2]^{+}\left(\mathrm{PF}_{6}\right)$} & 0.13 &
\end{tabular}

As complexes $[\mathbf{1}]^{+}\left(\mathrm{PF}_{6}\right)$ display absorption at longer wavelengths in the visible part, we also carried out the irradiation at $546 \mathrm{~nm}$ in order to evaluate the efficiency at this wavelength as the ruthenium-nitrosyl fragment has a dominant contribution at this wavelength. The $\Phi_{\text {No }}$ decreased at longer $\lambda_{\text {irr }}$, but the complexes remain photoactive, as also observed by Ghosh. ${ }^{29}$

In addition, it should be noted that the final spectra after photoinduced NO release are similar for $\left[\mathbf{1 c}^{+}\right]^{+}\left(\mathrm{PF}_{6}\right)$ and $[\mathbf{1 t}]^{+}\left(\mathrm{PF}_{6}\right)$. We already reported the same observation: cis and trans isomers lead to the same photoproduct, the trans solvated product. ${ }^{12}$ The structure of photoproduct $[4]^{+}\left(\mathrm{PF}_{6}\right)$ is shown on Fig. 5 and crystal data are given in Table S5 (ESI).

6 | J. Name.

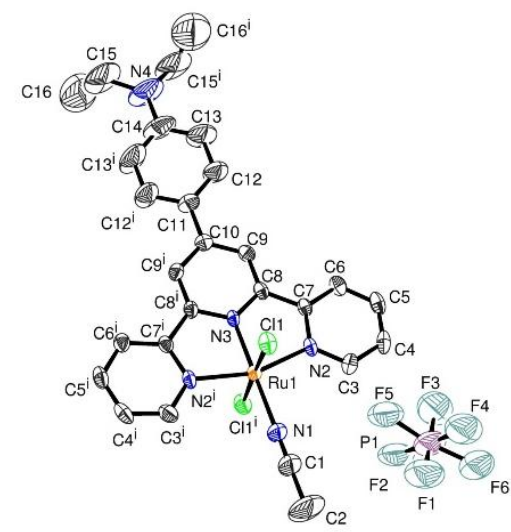

Fig. 5: Molecular structure of the photoproduct $[4]^{+}\left(\mathrm{PF}_{6}\right)$. Displacement ellipsoids are drawn at $50 \%$ probability level. Hydrogen atoms are omitted for clarity.

We can corroborate the conclusions from electrochemical measurements: photorelease of $\mathrm{NO}$ leads to a $\mathrm{Ru}^{\text {III }}$ complex as demonstrated by the presence of one $\left(\mathrm{PF}_{6}\right)^{-}$as counter-anion. The nitrosyl ligand is replaced by a molecule of solvent used for irradiation, ie acetonitrile. Selected bonds and angles are given Table S6 (ESI). We can observe the appearance of a large band at $\approx$ $1000 \mathrm{~nm}$, on the UV-visible spectrum of $[4]^{+}\left(\mathrm{PF}_{6}\right) \quad$ (Fig. S6, ESI). Although large drawn against the light wavelength, the bandwidth in energy at half-maximum is equal to $3800 \mathrm{~cm}^{-1}$ and is readily attributed to a single transition predicted at $1241 \mathrm{~cm}^{-1}$ by DFT calculation (Table 1). The agreement between computation and experiment $\left(\approx 240 \mathrm{~cm}^{-1}\right)$ appears therefore excellent, together with the reduced intensity of this low-lying transition. ${ }^{21}$ Interestingly, the charge transfer direction observed from the aniline towards the NO-containing metal fragment, in all instances, is reversed from the metal (HOMO) to the aniline (LUMO) in the photoproduct, due to the absence of the strongly withdrawing NO substituent.

\section{Materials and methods,}

\section{Materials}

2-acetylpyridine and the $\mathrm{N}$-diethylamino-4-benzaldehyde were obtained from Alfa-Aesar; copper was furnished by Sigma-Aldrich and $\mathrm{RuCl}_{3} \cdot \mathrm{nH}_{2} \mathrm{O}$ by Strem; the solvents were analytical grade and used without further purification. $\mathrm{K}_{2}\left[\mathrm{RuCl}_{5} \mathrm{NO}\right]$ was prepared as decribed. $^{30}$

\section{Instruments}

Elemental analyses were performed at LCC with a Perkin Elmer 2400 serie II Instrument. ${ }^{1} \mathrm{H}$ and ${ }^{13} \mathrm{C}$ NMR spectra were obtained at $298 \mathrm{~K}$ in $\mathrm{CDCl}_{3}, \mathrm{CD}_{3} \mathrm{CN}$ or $\left(\mathrm{CD}_{3}\right)_{2} \mathrm{SO}$ taking as internal reference and were recorded on a Bruker Avance $400\left(400 \mathrm{MHz}\right.$ for ${ }^{1} \mathrm{H}$ NMR and $100 \mathrm{MHz}$ for $\left.{ }^{13} \mathrm{C}\right)$. $J$ values are given in Hertz. Electrospray lonization Mass Spectroscopy measurements were carried out on a Xevo G2 Q TOF (Waters) spectrometer.

Separation of the complexes was achieved by preparative HPLC on Acquity chain (Waters SA) with UV-Vis detector diode array (200$800 \mathrm{~nm}$ ). The used column is Acquity BEH C18 $50 \mathrm{~mm} \times 2.1 \mathrm{~mm}$ (inverse phase). Elution was carried out with a mixture of water acidified with $1 \%$ of trifluoroacetic acid and acetonitrile, in variable proportions with time.

Voltammetric measurements were carried out using a potentiostat Autolab PGSTAT100. The experiments were performed at room temperature in a home-made airtight three electrode cell connected to a vacuum/argon line. The reference electrode consisted of a saturated calomel electrode (SCE) separated from the solution by a bridge compartment. The counter electrode was a platinum wire of $c a .1 \mathrm{~cm}^{2}$ apparent surface. The working electrode was a Pt microdisk ( $0.5 \mathrm{~mm}$ diameter). The supporting electrolyte 
$\left[n \mathrm{Bu}_{4} \mathrm{~N}\right]\left(\mathrm{PF}_{6}\right)$ (Fluka, 99\% puriss electrochemical grade) was used as received and simply degassed by bubbling argon. Acetonitrile (MeCN) of CHROMASOLV ${ }^{\circledR}$ grade (gradient grade) was obtained from Aldrich (>99.99\%). The solution concentrations used for electrochemical studies were typically $1 \mathrm{mM}$ in complex and $0.1 \mathrm{M}$ in the supporting electrolyte. Before each measurement, the solutions were degassed by bubbling argon and the working electrode was polished with a polishing machine (Presi P).

The UV-visible spectra were obtained on a Hewlett Packard 8454A diode array spectrophotometer.

One photon photolysis experiments were performed with a Muller reactor device equipped with a $200 \mathrm{~W}$ mercury vapor bulb, a cooling water filter and interference filters. Light intensities were determined before each photolysis experiments by chemical actinometry procedure with potassium ferrioxalate for $\lambda_{\text {irr }}=365$ $\mathrm{nm}$ and Reinecke salt for $\lambda_{\text {irr }}=542 \mathrm{~nm}$. For $\lambda_{\text {irr }}=365 \mathrm{~nm}, \mathrm{I}_{0}=$ 8.84.10 ${ }^{-6} \mathrm{M} . \mathrm{s}^{-1}, \lambda_{\text {obs }}=340 \mathrm{~nm}$ for $[1 \mathrm{c}]^{+}\left(\mathrm{PF}_{6}\right), \mathrm{I}_{0}=9.42 .10^{-6} \mathrm{M} . \mathrm{s}^{-1} \lambda_{\text {obs }}$ $=450 \mathrm{~nm}$ for $[1 \mathrm{tt}]^{+}\left(\mathrm{PF}_{6}\right)$ and $\mathrm{I}_{0}=1.13 .10^{-6} \mathrm{M} \cdot \mathrm{s}^{-1} \lambda_{\text {obs }}=320 \mathrm{~nm}$ for

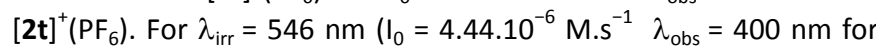
$[\mathbf{1 c}]^{+}\left(\mathrm{PF}_{6}\right)$ and $[\mathbf{1 t}]^{+}\left(\mathrm{PF}_{6}\right)$.

\section{Syntheses}

4'-NEt ${ }_{2} \mathrm{Ph}-2,2^{\prime}: 6^{\prime}, 2^{\prime \prime}$-terpyridine ( $\mathrm{NEt}_{2}$-Phtpy):

To a solution of 2-acetylpyridine $(1.12 \mathrm{~mL}, 10 \mathrm{mmol}$ ) in ethanol (15 $\mathrm{mL})$ was added $1 \mathrm{~mL}$ of aqueous $\mathrm{NaOH}(10 \mathrm{M})$. 4Diethylaminebenzaldehyde $(885 \mathrm{mg}, 5 \mathrm{mmol})$ was added and the reaction mixture was refluxed for 4 hours. After cooling down, the solvent was evaporated to dryness and the resulting paste was taken in $50 \mathrm{~mL}$ of $95 \% \mathrm{EtOH}$. After few hours, some precipitate appeared. It was filtrated and gave $690 \mathrm{mg}$ of pale yellow powder. The next day some more precipitate appeared in the filtrate and gave $155 \mathrm{mg}$ of the compound. Yield: $44 \%$.

${ }^{1} \mathrm{H}\left(400 \mathrm{MHz} ; \mathrm{CD}_{3} \mathrm{CN}\right) \delta$ (ppm): 8.75 (ddd, J = 4.8; $\left.1.8 ; 1 \mathrm{~Hz}, 2 \mathrm{H}\right), 8.73$ $(\mathrm{s}, 2 \mathrm{H}), 8.70(\mathrm{dt}, \mathrm{J}=7.9 ; 1.1 \mathrm{~Hz}) ; 7.98(\mathrm{td}, \mathrm{J}=7.5 ; 1.8 \mathrm{~Hz}, 2 \mathrm{H}) ; 7.83(\mathrm{~d}$, $\mathrm{J}=9 \mathrm{~Hz}, 2 \mathrm{H}$ ); 7.46 (ddd, J = 7.5; 4.8; $1.2 \mathrm{~Hz}, 2 \mathrm{H}) ; 6.89(\mathrm{~d}, \mathrm{~J}=9 \mathrm{~Hz}$ $2 \mathrm{H}) ; 3.49(\mathrm{q}, \mathrm{J}=7.1 \mathrm{~Hz}, 4 \mathrm{H}) ; 1.22(\mathrm{t}, \mathrm{J}=7.0 \mathrm{~Hz}, 6 \mathrm{H}) .{ }^{13} \mathrm{C}\left(\mathrm{CDCl}_{3}\right)$ : $156.76 ; 155.65 ; 150.01 ; 149.06 ; 148.53 ; 136.78 ; 128.29 ; 124.42$; $123.58 ; 121.37 ; 117.33 ; 111.61 ; 44.42 ; 12.64$.

Synthesis of $[\mathbf{1} \mathbf{c}]^{+}\left(\mathrm{PF}_{6}\right)$ and $[\mathbf{1 t}]^{+}\left(\mathrm{PF}_{6}\right)$ cis/trans- $(\mathrm{Cl}, \mathrm{Cl})-\left[\mathrm{Ru}\left(\mathrm{NEt}_{2-}\right.\right.$ Phtpy) $\left.\mathrm{Cl}_{2}(\mathrm{NO})\right]^{+}\left(\mathrm{PF}_{6}\right)$

$\mathrm{K}_{2}\left[\mathrm{RuCl}_{5} \mathrm{NO}\right]$ (116 mg, $0.3 \mathrm{mmol}$ ) was added in a mixture of $\mathrm{EtOH} / \mathrm{H}_{2} \mathrm{O}(3 / 1 ; 24 \mathrm{~mL})$. After addition of $\mathrm{KCl}(290 \mathrm{mg}, 3.9 \mathrm{~mol})$, the mixture was refluxed. $\mathrm{NEt}_{2}$-Phtpy (100mg, $0.26 \mathrm{mmol}$ ) was added in small portions over a period of half an hour. At the end of the addition, heating was maintained for 35 min. After cooling down, the solvents were evaporated off and the mixture was submitted to inverse HPLC chromatography to isolate the cis and trans isomers. After separation of the isomers, metathesis was carried out as follows: the pure isomer was solubilized in a small amount of DMF and an excess of a saturated solution of $\mathrm{NH}_{4} \mathrm{PF}_{6}$ was added. The obtained precipitate was filtered, rinsed with water and dried in a desiccator.

$[1 \mathrm{c}]^{+}\left(\mathrm{PF}_{6}\right)$
${ }^{1} \mathrm{H}$ NMR (400 MHz; CD $\left.{ }_{3} \mathrm{CN}\right) \delta(\mathrm{ppm}) 9.19(\mathrm{dd}, \mathrm{J}=5.6$ and $1.6 \mathrm{~Hz}, 2 \mathrm{H})$; $8.72(\mathrm{~d}, \mathrm{~J}=8.4 \mathrm{~Hz}, 2 \mathrm{H}) ; 8.70(\mathrm{~s}, 2 \mathrm{H}) ; 8.46(\mathrm{dt} \mathrm{J}=8.0$ and $1.6 \mathrm{~Hz}, 2 \mathrm{H})$; $8.08(\mathrm{~d}, \mathrm{~J}=8.8 \mathrm{~Hz}, 2 \mathrm{H}$ ); 7.95(ddd, $\mathrm{J}=7.6,6.0$ and $1.2 \mathrm{~Hz}, 2 \mathrm{H}$ ); $6.98(\mathrm{~d}, \mathrm{~J}=8.8 \mathrm{~Hz}, 2 \mathrm{H}) ; 3.52(\mathrm{q}, \mathrm{J}=6.8 \mathrm{~Hz}) ; 1.25(\mathrm{t}, \mathrm{J}=6.8 \mathrm{~Hz}) . \mathrm{IR}$ (ATR) $: v_{\mathrm{NO}}=1891 \mathrm{~cm}^{-1}$. ESI-MS: $\mathrm{m} / \mathrm{z}=582.0406[\mathrm{M}]^{+}$.

$[\mathbf{1 t}]^{+}\left(\mathrm{PF}_{6}\right)$

${ }^{1} \mathrm{H}$ NMR (400 MHz; $\mathrm{CD}_{3} \mathrm{CN}$ ) $\delta(\mathrm{ppm}): 8.74(\mathrm{dd}, \mathrm{J}=5.7$ and $1.3 \mathrm{~Hz}$, $2 \mathrm{H}) ; 8.53(\mathrm{dd}, \mathrm{J}=8.0$ and $1.3 \mathrm{~Hz}, 2 \mathrm{H}) ; 8.46(\mathrm{~s}, 2 \mathrm{H}) ; 8.26(\mathrm{dt} \mathrm{J}=8.0$ and $1.4 \mathrm{~Hz}, 2 \mathrm{H}) ; 7.98(\mathrm{~d}, \mathrm{~J}=8.8 \mathrm{~Hz}, 2 \mathrm{H}) ; 7.81$ (ddd, $\mathrm{J}=7.7 ; 5.7$ and 1.3 $\mathrm{Hz}, 2 \mathrm{H}) ; 6.86(\mathrm{~d}, \mathrm{~J}=8.8 \mathrm{~Hz}, 2 \mathrm{H}) ; 3.52(\mathrm{q}, \mathrm{J}=6.8 \mathrm{~Hz}) ; 1.25(\mathrm{t}, \mathrm{J}=$ $6.8 \mathrm{~Hz}) .{ }^{13} \mathrm{C}\left\{{ }^{1} \mathrm{H}\right\} \mathrm{NMR}\left(100 \mathrm{MHz} ; \mathrm{CD}_{3} \mathrm{CN}\right): 155.5 ; 155.1 ; 153.9 ; 152.3$; $151.4 ; 142.2 ; 130.1 ; 129.6 ; 126.0 ; 119.4 ; 119.1 ; 112.0 ; 44.4 ; 11.9$. Elemental analysis (\%): calc. for $\mathrm{C}_{25} \mathrm{H}_{24} \mathrm{~N}_{5} \mathrm{RuOCl}_{2} \mathrm{PF}_{6}, \mathrm{C}: 41.28$; $\mathrm{H}$ : 3.33; N: 9.63 found C: 40.96; H: 3.24; N: 10.18. IR (ATR) $: v_{\mathrm{NO}}=1898$ $\mathrm{cm}^{-1}$. ESI-MS: $\mathrm{m} / \mathrm{z}=582.0400[\mathrm{M}]^{+}$.

Synthesis of $[\mathbf{2 c}]^{+}\left(\mathrm{PF}_{6}\right)$ and $[\mathbf{2 t}]^{+}\left(\mathrm{PF}_{6}\right)$ cis/trans- $(\mathrm{Cl}, \mathrm{Cl})-[\mathrm{Ru}(\mathrm{NEt}(\mathrm{NO})-$ Phtpy) $\left.\mathrm{Cl}_{2}(\mathrm{NO})\right]^{+}\left(\mathrm{PF}_{6}\right)$

The synthesis deals with two steps:

1) synthesis of $\left[\mathrm{Ru}\left(\mathrm{NEt}_{2}-\mathrm{Phtpy}\right) \mathrm{Cl}_{3}\right]$

$\left[\mathrm{Ru}\left(\mathrm{NEt}_{2}-\mathrm{Phtpy}\right) \mathrm{Cl}_{3}\right]$ was obtained as previously reported on other terpyridine ligands. ${ }^{12}$

In a flask with $40 \mathrm{~mL}$ of ethanol were added $\mathrm{RuCl}_{3} .2 \mathrm{H}_{2} \mathrm{O}(79 \mathrm{mg}, 0.3$ mmol.) and $\mathrm{NEt}_{2}$-Phtpy (114 mg, $0.3 \mathrm{mmol}$.). The mixture was refluxed for 3 hours in the dark. After cooling down, the black precipitate was filtered off, rinsed with distilled water, ethanol, diethyloxide and dried in a desiccator.

\section{2) $[\mathbf{2 c}]^{+}\left(\mathrm{PF}_{6}\right)$ and $[\mathbf{2 t}]^{+}\left(\mathrm{PF}_{6}\right)$}

[Ru(NEt $\left.{ }_{2}-\mathrm{Phtpy} \mathrm{Cl}_{3}\right](188 \mathrm{mg}, 0.32 \mathrm{mmol})$ was solubilized in $7 \mathrm{~mL}$ of DMF and warmed at $80^{\circ} \mathrm{C}$. NO gas, generated by adding nitric acid on copper under $\operatorname{argon}^{30}$, was bubbled in the solution for 2 hours. The color turned from dark-brown to violet. After stopping the heating, when opening the reaction flask under the hood to the air, we observed that the color of the solution changed from violet to red-brown. The solvent was evaporated to dryness and gave 168 $\mathrm{mg}$ of a brownish powder. ${ }^{1} \mathrm{HNMR}$ of the crude product indicated a $10 / 90$ ratio of cis/trans isomers. The mixture was submitted to HPLC for the separation of the two isomers and gave $59 \mathrm{mg}$ (yield = $25 \%$ ) of trans isomer and traces of cis isomer after metathesis.

\section{$[\mathbf{2 t}]^{+}\left(\mathrm{PF}_{6}\right)$}

${ }^{1} \mathrm{H}$ NMR (400 MHz; $\left.\mathrm{CD}_{3} \mathrm{CN}\right) \delta(\mathrm{ppm}): 8.82(\mathrm{~m}, 2 \mathrm{H}) ; 8.81(\mathrm{~s}, 2 \mathrm{H})$; $8.72(\mathrm{ddd}, \mathrm{J}=8.0 ; 1.4$ and $0.7 \mathrm{~Hz}, 2 \mathrm{H}$ ); $8.44(\mathrm{dt}, \mathrm{J}=7.9$ and $1.4 \mathrm{~Hz}, 2 \mathrm{H}$ ); $8.25(\mathrm{~d}, \mathrm{~J}=8.8 \mathrm{~Hz}, 2 \mathrm{H}) ; 7.98(\mathrm{~d}, \mathrm{~J}=8.8 \mathrm{~Hz}, 2 \mathrm{H}) ; 7.91$ (ddd, J = 7.8; 5.7 and $1.4 \mathrm{~Hz}, 2 \mathrm{H}$ ); 4.19 (quad, $\mathrm{J}=7.2 \mathrm{~Hz}$ ); $1.22\left(\mathrm{t}, \mathrm{J}=7.2 \mathrm{~Hz}\right.$ ). ${ }^{13} \mathrm{C}\left\{{ }^{1} \mathrm{H}\right\}$ NMR (100MHz; $\left.\mathrm{CD}_{3} \mathrm{CN}\right) \delta$ (ppm): 155.3; 155.0; 154.2; 153.2; 144.4; $142.5 ; 133.1 ; 130.1 ; 129.8 ; 126.7 ; 122.7 ; 119.5 ; 38.4 ; 11.0$. Elemental analysis (\%): calc. for $\mathrm{C}_{23} \mathrm{H}_{19} \mathrm{~N}_{6} \mathrm{RuO}_{2} \mathrm{Cl}_{2} \mathrm{PF}_{6}, \mathrm{C}$ : 37.93; $\mathrm{H}$ : 2.63; N: 11.54 with $\mathrm{PF}_{6}$. found C: $38.64 ; \mathrm{H}: 2.50 ; \mathrm{N}: 10.91$. IR (ATR) : $v_{\mathrm{NO}}=1894 \mathrm{~cm}^{-1}$. ESI-MS: $\mathrm{m} / \mathrm{z}=582.9993[\mathrm{M}]^{+}$.

\section{$[\mathbf{3 t}]^{+}\left(\mathrm{PF}_{6}\right)$ by nitration of $[\mathbf{1 t}]^{+}\left(\mathrm{PF}_{6}\right)$}

${ }^{1} \mathrm{H}$ NMR (400 MHz; $\left.\mathrm{CD}_{3} \mathrm{CN}\right) \delta$ (ppm): $8.78(\mathrm{~d}, \mathrm{~J}=5.2 \mathrm{~Hz}, 2 \mathrm{H}) ; 8.71(\mathrm{~d}$, $\mathrm{J}=7.7 \mathrm{~Hz}, 2 \mathrm{H}) ; 8.70(\mathrm{~s}, 2 \mathrm{H}) ; 8.50(\mathrm{~d}, \mathrm{~J}=2.5 \mathrm{~Hz}, 1 \mathrm{H}) ; 8.42(\mathrm{dt}, \mathrm{J}=7.9$; $1.5 \mathrm{~Hz}, 2 \mathrm{H}$ ); 8.18 (dd, $\mathrm{J}=9$ and $2.5 \mathrm{~Hz}, 1 \mathrm{H}$ ); 7.89 (ddd, J = 7.8; 5.6 
and $1.4 \mathrm{~Hz}, 2 \mathrm{H}) ; 7.44(\mathrm{~d}, \mathrm{~J}=8.9 \mathrm{~Hz}, 1 \mathrm{H}) ; 3.42(\mathrm{q}, \mathrm{J}=7.1 \mathrm{~Hz}, 4 \mathrm{H}) ; 1.23$ $(\mathrm{t}, \mathrm{J}=7.1 \mathrm{~Hz}, 6 \mathrm{H})$.

\section{Computational details}

The four $\left([\mathbf{1} \mathbf{c}]^{+},[\mathbf{1 t}]^{+},[\mathbf{2 t}]^{+}\right.$, and $\left.[\mathbf{4}]^{+}\right)$ruthenium complexes were fully optimized using the Gaussian-09 program package ${ }^{32}$ within the framework of the density functional theory (DFT) at the PBE0/631G* level. ${ }^{33,34}$ The PBEO functional was selected in agreement with our previous investigations which revealed that PBEO performed better than the widely used B3LYP and B3PW91 functionals, to reproduce the geometry of $\left[\mathrm{Ru}^{\text {II }}(\mathrm{R}-\mathrm{Phtpy}) \mathrm{Cl}_{2}(\mathrm{NO})\right]^{+}$species. ${ }^{11,12}$ The LANL2DZ basis set was applied for the heavy ruthenium atom, to account for the relativistic effects. ${ }^{35}$ The computations were performed in acetonitrile medium, using the polarizable continuum model (PCM) in the SCRF procedure available in Gaussian09. ${ }^{36}$ The vibrational analyses were conducted at the same level to verify that the stationary points correspond to minima on the potential energy surfaces. No symmetry requirement was considered first. Nevertheless, the $C_{2}$ symmetry was found for $[\mathbf{1} t]^{+}$, within a tolerance of $0.002 \AA$. Therefore, the final computations were performed within this symmetry for this complex. In the case of photoproduct $[4]^{+}$, although the presence of a methyl on the acetonitrile ligand prohibits any symmetry, it is worth pointing out that the optimized molecule in which the methyl fragment is removed exhibits the $C_{2}$ symmetry, within a tolerance of $0.13 \AA$.

The computations of the UV-visible spectra in acetonitrile medium were performed at the same PBE0/6-31G* level. This TD-DFT method was selected for a consistency with our previously reported study of $\left[\mathrm{Ru}^{\prime \prime}(\mathrm{R}-\mathrm{Phtpy}) \mathrm{Cl}_{2}(\mathrm{NO})\right]^{+}$species. ${ }^{12}$ Additionally, PBEO was found to reproduce the energy of the low-lying charge transfer transition of $[\mathbf{1 t}]^{+}$within a discrepancy of less than $3000 \mathrm{~cm}^{-1}$, which is better than the standard B3LYP, CAM-B3LYP, or B3PW91 method, and which is found to fall in the common range of uncertainty, taking into account the presence of heavy (Ru) atom and long range charge-transfer effects (see ESI). ${ }^{37}$

\section{Crystallography}

Data were collected at low temperature (100(2) K) on a Bruker Kappa Apex II diffractometer equipped with a $30 \mathrm{~W}$ air-cooled microfocus, using MoK $\alpha$ radiation $(\lambda=0.71073 \AA)$, and an Oxford Cryosystems Cryostream cooler device. Phi- and omega- scans were used for data collection. An empirical absorption correction with SADABS was applied. ${ }^{38}$ The structure were solved by intrinsic phasing method (SHELXT). ${ }^{39}$ All non-hydrogen atoms were refined anisotropically by means of least-squares procedures on $F^{2}$ with SHELXL. ${ }^{40}$ All the hydrogen atoms were refined isotropically at calculated positions using a riding model with their isotropic displacement parameters constrained to be equal to 1.5 times the equivalent isotropic displacement parameters of their pivot atoms for terminal $\mathrm{sp}^{3}$ carbon and 1.2 times for all other carbon atoms. CCDC 1911757-1911760.

\section{Conclusions}

We have synthetized ruthenium-nitrosyl complexes which were able to release NO upon irradiation. The use of a tpy ligand bearing $\mathrm{NEt}_{2}$ as electron-donating ligand led to complexes with absorption bands in the visible part. However, quantum yields of NO release greatly decreased when irradiation was conducted with visible light instead of UV light. This result shows that experimental data need a more sophisticated conceptual approach. We have also shown that the reactivity of the ligand once coordinated to the ruthenium ion may be affected. One important point concerning the NO delivery, is that in ruthenium-nitrosyl complexes, the nitrosyl ligand should be trans to a chlorido ligand to enhance the NO release efficiency. This is in line with previous results ${ }^{12,41}$ and opens new insights in the conception of next rutheniumnitrosyl complexes.

\section{Conflicts of interest}

"There are no conflicts to declare"

\section{Acknowledgements}

We gratefully acknowledge the funding support received for the Centre National de la Recherche Scientifique (CNRS) and ERASMUS program for S. A.'s fellowship. We thank Isabelle Fabing for her technical assistance with the Acquity chain (Waters SA) provided by the Integrated Screening Platform of Toulouse (PICT, IBiSA).

\section{Notes and references}

1 L.J. Ignarro, FASEB Journal, 1989, 3, 31-36; L.J. Ignarro, Angew. Chem. Int. Ed. 1999, 38, 1882-1892.

2 D.S. Bredt, P.M. Hwang, S.H. Snyder, Nature, 1990 347, 76 8770; J. Garthwaite, Trends in Neurosciences, 1991, 14, 60-67; J. Garthwaite, Trends in Neurosciences, 1995, 18, 51-52.

3 J.B. Hibbs Jr., R.R. Taintor, Z. Vavrin, E.M. Rachlin, Biochem. Biophys. Res. Commun., 1988, 157, 87-94; M.A. Marletta, P.S. Yoon, R. lyengar, C.D. Leaf, J.S. Wishnok, Biochemistry, 1988, 27, 8706-8711.

4 D. Alonso, M. W. Radomski, Heart Failure Reviews 2003, 8,47-54.

5 R. A. Cohen, R. M. Weisbrod, M. Gericke, M. Yaghoubi, C. Bierl, V. M. Bolotina, Circ Res. 1999, 84, 210-21; B. W. Allen, J. S. Stamler, C. A. Piantadosi Trends Mol Med. 2009, 10, 452-460;

Y. Zhao, P.M. Vanhoutte, S.W.S. Leung J. Pharmaceut. Sciences, 2015, 129, 83-94.

6 L. Morbidelli, S. Donnini, M. Ziche, Curr. Pharm. Des., 2003, 9, 521-30.

7 P.C Ford, J. Bourassa, K. Miranda, B. Lee, I. Lorkovic, S. Boggs, S. Kudo, L. Laverman Coord. Chem. Rev. 1998, 171, 185-202; P. C. Ford Acc. Chem. Res. 2008, 41, 190-200; H.-J. Xiang, M. Guo, J.-G. Liu Eur. J. Inorg. Chem. 2017, 1586-1595.

8 M.J. Rose, P. K. Mascharak Curr. Opin. Chem. Biol.,2008, 12, 238-244.

9 T. R. de Boer, P. K.Mascharak, Adv. Inorg. Chem. 2015, 67, 145-170 ; E. Tfouni, D. R. Truzzi, A. Tavares, A. J. Gomes, L. E. Figueiredo, D. W. Franco Nitric Oxide, 2012, 26, 38-53 ; F. G. Doroa, K. Q. Ferreira, Z. Novais da Rocha,,G. F. Caramoric, A. J. Gomes, E. Tfouni Coord. Chem. Rev. 2016, 306, 652-677.

10 J. Akl, I. Sasaki, P. G. Lacroix, V. Hugues, M. Bocé, S. MalletLadeira, P. Vivendo, M. Blanchard-Desce, I. Malfant, 
Photochem. Photobiol Sci., 2016, 15, 1484-1491; M. Bocé, M. Tassé, S. Mallet-Ladeira, F. Pillet, C. Da Silva, P. Vicendo, P.G. Lacroix, I. Malfant, M.P. Rols, Scientific Reports, 2019, 9, 4867.

11 J. Akl, C. Billot, P. G. Lacroix, I. Sasaki, S. Mallet-Ladeira, I. Malfant, R. Arcos-Ramos, M. Romero, N. Farfán New J. Chem., 2013, 37, 3518-3527.

12 S. Amabilino, M. Tasse, P.G. Lacroix, S. Mallet-Ladeira, V. Pimienta, J. Akl, I. Sasaki, I. Malfant, New. J. Chem. 2017,41, 7371-7383

13 J. Sanz García, F. Alary, M. Boggio-Pasqua, I. M. Dixon, J.-L. Heully J. Mol. Model. 2016, 22, 284.

14 T. Becker, S. Kupfer,M. Wolfram, H. Gçrls, U. S. Schubert, E. V. Anslyn, B. Dietzek, S. Gräfe , A. Schiller Chem. Eur. J. 2015 21, 15554-15563; N. L. Fry, P. K. Mascharak Acc Chem. Res. 2011, 44, 289-298.

15 R. Cammack, C.L. Joannou, X.-Y. Cui, C. Torres Martinez, S. R. Maraj, M. N. Hughes Biochim. Biophys. Acta 1999, 1411, 475488.

16 S. Shephard, W. K. Lutz, Cancer surveys, 1989, 8, 401-421.

17 D.L.H. Williams, Nitrosation reactions and chemistry of nitric oxide 2004, Elsevier B.V.Amsterdam, p 46-47.

18 A.R. Butler, D.L.H. Williams Chem. Soc. Rev. 1993, 22, 233 241.

19 T. Itoh, Y. Matsuya, H. Maeta, M. Miyazaki, K. Nagata, A. Ohsawa Chem. Pharm. Bull. 1999, 47, 819-823.

20 P. Zhang, M. Cedilote, T. P. Cleary, M. E. Pierce Tetrahedron Lett. 2007, 48, 8659-8664; L. Wang, X. Pan, Y. Zhao, Y. Chen, W. Zhang, Y. Tu, Z. Zhang, J. Zhu, N. Zhou, X. Zhu Macromolecules 2015, 48, 1289-1295.

21 D. N. Huh, E. T. Czer, K. E. Cordova, W. I. Chow, C. E. Moore, A. L. Rheingold, C. J.A. Daley Inorg. Chim. Acta 2016, 450 236-242.

22 D. Laurent, D. Jacquemin, Int. J. Quant. Mech. 2013, 20192039.

23 B. J. Coe, S. J. Glenwright Coord. Chem. Rev. 2000, 203, 5-80.

24 H. Nagao, K. Enomoto, Y. Wakabayashi, G. Komiya, T. Hirano, T. Oi, Inorg. Chem., 2007, 46, 1431-1439.

25 S. Maji, B. Sarkar, M. Patra, A. K. Das, S. M. Mobin, W. Kaim, G. K. Lahiri, Inorg. Chem., 2008, 47, 3218-3227.

26 P. De, B. Sarkar, S. Maji, A. K. Das, E. Bulak, S. M. Mobin, W. Kaim, G. K. Lahiri, Eur. J. Inorg. Chem., 2009, 2702-2710.

27 E. T. Seo, R. F. Nelson, J. M. Fritsch, L. S. Marcoux, D. W. Leedy, R. N. Adams J. Am. Chem. Soc. 1966, 88, 3498-3503.

28 Sa3.3 software can be downloaded at http://cinet.chim.pagesperso-orange.fr/

29 R. Kumar, S. Kumar, M. Bala, A. Ratnam, U.P. Singh, K. Ghosh J. Organomet. Chem. 2018, 863, 77-83.

30 J.R. During, W.A. McAllister, J.N. Willis, E.E. Mercer Spectrochim. Acta, 1966, 22, 1091-1100.

31 J. Kotz, P. Treichel and J. Townsend, Chemistry and Chemical Reactivity, 7th edn, 2009, vol. 2, p. 996.

32 M. J. Frisch, G. W. Trucks, H. B. Schlegel, G. E. Scuseria, M. A. Robb, J. R. Cheeseman, G. Scalmani, V. Barone, B. Mennucci, G. A. Petersson, H. Nakatsuji, M. Caricato, X. Li, H. P. Hratchian, A. F. Izmaylov, J. Bloino, G. Zheng, J. L. Sonnenberg, M. Hada, M. Ehara, K. Toyota, R. Fukuda, J. Hasegawa, M. Ishida, T. Nakajima, Y. Honda, O. Kitao, H. Nakai, T. Vreven, J. A. Montgomery, Jr., J. E. Peralta, F. Ogliaro, M. Bearpark, J. J. Heyd, E. Brothers, K. N. Kudin, V. N. Staroverov, R. Kobayashi, J. Normand, K. Raghavachari, A. Rendell, J. C. Burant, S. S. Iyengar, J. Tomasi, M. Cossi, N. Rega, J. M. Millam, M. Klene, J. E. Knox, J. B. Cross, V. Bakken, C. Adamo, J. Jaramillo, R. Gomperts, R. E. Stratmann, O. Yazyev, A. J. Austin, R. Cammi, C. Pomelli, J. W. Ochterski, R. L. Martin, K. Morokuma, V. G. Zakrzewski, G. A. Voth, P. Salvador, J. J. Dannenberg, S. Dapprich, A. D. Daniels, O. Farkas, J. B. Foresman, J. V. Ortiz, J. Cioslowski and D. J. Fox, Gaussian 09, Revision A.02, Gaussian, Inc., Wallingford, CT, 2009.

33 J. P. Perdew, K. Burke and M. Ernzerhof, Phys. Rev. Lett., 1997, 78, 1396-1396; J. P. Perdew, K. Burke and M. Ernzerhof, Phys. Rev. Lett., 1996, 77, 3865-3868.

34 C. Adamo and V. Barone, J. Chem. Phys., 1999, 110, 61586169.

35 P. J. Hay and W. R. Wadt, J. Chem. Phys., 1985, 82, 270-283; W. R. Wadt, P. J. Hay, J. Chem. Phys., 1985, 82, 284-298; P. J. Hay, W. R. Wadt, J. Chem. Phys., 1985, 82, 299-310.

36 J. Tomasi, B. Mennucci and R. Cammi, Chem. Rev., 2005, 105 2999-3093.

37 A.D. Laurent, D. Jacquemin, Int. J. Quant. Mech. 2013, 20192039.

38 SADABS. Bruker AXS Inc. Madison, Wisconsin, USA.

39 G.M. Sheldrick, Acta Cryst. 2015, A71, 3-8.

40 G.M. Sheldrick, Acta Cryst. 2008, A64, 112-122.

41 V. Bukhanko, P. G. Lacroix, I. Sasaki, M. Tassé, S. MalletLadeiraa, Z. Voitenko, I. Malfant, Inorg. Chim. Acta, 2018, 482, 195-205; M.Roose, I.Sasaki, V.Bukhanko, S.MalletLadeira, R.M.Barba-Barba, G. Ramos-Ortiz, A. EnriquezCabrera, N. Farfan, P. G. Lacroix and I. Malfant, Polyhedron, 2018, 151, 100-111. 